\title{
Baraj Yıkılması Sonrası İki Boyutlu Taşkın Yayılımının Yerleşim Bölgeleri İçin Modellenmesi
}

\author{
Şebnem ELÇi ${ }^{1}$ \\ Gökmen TAYFUR ${ }^{2}$ \\ İsmail HALTAS ${ }^{3}$ \\ Bülent KOCAMAN ${ }^{4}$
}

\section{ÖZ}

Her ne kadar baraj yıkılması nadiren gerçekleşse de, aniden yıkılan bir barajın taşkın dalgasının mansapta bulunan yerleşim bölgelerinde etkisi felaketle sonuçlanabilmektedir. $\mathrm{Bu}$ sebeble muhtemel bir baraj yıkılmasının sonuçlarını öngörmek risk yönetimi açısından gereklidir. Bu çalışmada baraj yıkılması sonucunda oluşan taşkın dalgasının tahmini ve mansapta ilerlemesinin analizine yönelik bir yaklaşım sunulmuştur. Sunulan yaklaşım, barajların aniden yıkılma varsayımı ile baraj haznesindeki su hacminin bir-boyutlu model ile dar bir vadi boyunca ötelenmesini ve ötelenmiş hidrograf sınır şartı kabul edilerek mansabında yerleşim bölgeleri yer alan iki ayrı çalışma alanında taşkın dalgasının iki boyutlu yayılımının modellenmesini içermektedir. Önerilen yaklaşım mansabında Eskişehir bulunan Porsuk Barajı ile mansabında İstanbul olan Alibey Barajına uygulanmışıır.

Anahtar Kelimeler: Baraj yıkılması sonrası akım, taşkın dalgasının ötelenmesi, HECRAS, FLO-2D, Porsuk Baraj1, Alibey Barajı.

\section{ABSTRACT \\ Numerical Modeling of Two Dimensional Flood Wave Propagation in Residential Areas After the Dambreak}

Although dam break failures are very rare events, dams can fail with little warning and the damage at the downstream of the dam due to the flood wave can be catastrophic. Therefore from risk point of view, understanding the consequences of a possible dam failure is critically important. This study discusses a methodology utilized for predicting the flood wave occurring after the dam break and analyzes the propagation of the flood wave

\footnotetext{
Not: Bu yazı

- $\quad$ Yayın Kurulu'na 28.08.2015 günü ulaşmıştır.

- 30 Eylül 2017 gününe kadar tartışmaya açıktır.

- DOI: $10.18400 /$ tekderg.307456
}

1 İzmir Yüksek Teknoloji Enstitüsü, İnşaat Mühendisliği Bölümü, İzmir - sebnemelci@iyte.edu.tr 2 İzmir Yüksek Teknoloji Enstitüsü, İnşaat Mühendisliği Bölümü, İzmir - gokmentayfur@iyte.edu.tr 3 Zirve Üniversitesi, İnşaat Mühendisliği Bölümü, Gaziantep - ismailhaltas@zirve.edu.tr 4 Turgut Özal Üniversitesi, İnşaat Mühendisliği Bölümü, Ankara - bkocaman@turgutozal.edu.tr 
Baraj Ylkılması Sonrası İki Boyutlu Taşkın Yayılımının Yerleşim Bölgeleri ...

downstream of the dam. Proposed methodology is applied to two dams; Porsuk dam located in Eskişehir and Alibey dam located in Istanbul, Turkey.

Keywords: Dam break flows, flood wave propagation, HEC-RAS, FLO-2D, Porsuk Dam, Alibey Dam.

\section{GİRIȘ}

Nadiren gerçekleşen bir baraj yıkılması durumunda, özellikle baraj membasında büyük hacimli bir hazne barındırıyorsa mansapta oluşan taşkın dalgası erozyon ve/veya yapısal yıkıma sebebiyet verecek kadar şiddetli olabilmektedir. Baraj yıkılması sonucu oluşan felaket genellikle ani olmakta ve ölümlerle sonuçlanmaktadır. Venedik, İtalya'da bulunan 267 m yüksekliğindeki Vajont beton kemer barajının 1963'te yıkılması iki binden fazla insanın ölümüne yol açarak tarihteki en büyük baraj yıkılması felaketlerinden birini oluşturmuştur [1]. İspanya'da bulunan Tous kaya dolgu barajı ise 1982'de uzun süreli bir yağış sonrası yıkılarak köy ve kasabaların da bulunduğu $300 \mathrm{~km}^{2}$ 'lik bir alanın sular altında kalmasına sebep olmuştur. Taşkın dalgasının yüksekliğinin 7 m’ye ulaştı̆̆ felaket sonucu, 100,000 kişi mansap bölgesinden tahliye edilmiş olmasına rağmen sekiz kişi hayatını kaybetmiş ve toplamda 200,000 kişi bu felaketten etkilenmiştir [2].

Çin dışında dünyanın değişik yerlerinden 900 yıkılan barajın bilgisinin derlendiği bir çalışmada yıkılan barajların \% 65.5'inin kaya dolgu, \% 7.5'unun beton, \% 6.7'sinin ise taş barajlar olduğu belirtilmiş, toprak dolgu barajların yıkılma sebepleri arasında \% 42.5 oranda teknik kusur, \% 36.5 taşma nedeniyle yıkımın gerçekleştiği, teknik kusurların ise \% 58.3'ünün gövdede borulanma, \% 18.3'ünün heyelan ve \% 9.1'inin de dolusavaktaki yetersizlikler kaynaklı olduğu belirtilmiştir [3].

Dünyada yapılan riskli barajları belirleme çalışmalarına benzer şekilde ülkemizde de DSİ, 2002 yılında yaptığı bir çalışma ile yüksekliği $15 \mathrm{~m}$ 'den büyük ve yükseklikleri $5-15 \mathrm{~m}$ arasında olup rezervuar hacmi $3 \mathrm{hm}^{3}$ 'ten büyük olan barajları incelemiş ve yıkılmaları halinde yaratacakları kayıplar düşünüldüğünde $\% 42$ 'sinin en yüksek risk derecesinde, \%43'ünün de önemli risk derecesine sahip olduğunu belirlemiştir [4]. Böylesi bir felaketle mücadele etmek için yapılacak planlama, yıkılma sonrası oluşacak muhtemel akım hızlarını ve taşkın dalgasının mansapta ne zaman nereye ulaşacağının tahminini içermeli ve mansapta yaşayan insanlarda felaketin muhtemel etkileri için farkındalık yaratabilmelidir.

Geçmişte genellikle bir boyutlu modellerin kullanıldığı baraj yıkılması sonrası taşkın dalgasının ötelenmesinin modellenmesine yönelik çalışmalar yapılmıştır. Bu çalışmalarda, Amerikan Hidrolojik Mühendislik Merkezi (HEC) tarafindan geliştirilen HECRAS ve Amerikan Ulusal Hava Servisi (NWS) tarafından geliştirilen FLDWAV modelleri birçok nehir ve dereye uygulanmıştır. Bu modeller doğal bir nehirde zamanla değişken akımı, su yüzeyinde küçük değişimler olduğu ve hidrostatik basınç dağılımı kabulüne dayanan bir boyutlu Saint Venant denklemleri yardımı ile çözebilmektedir. Saint Venant denklemlerinin uniform akım için kinematik dalga yaklaşımında ise momentum denkleminde tüm konumsal ve zamana bağlı değişkenler ihmal edilerek hidrografın yükselen ve alçalan eğrilerinde farklılık olmadığı kabulu yapılır [5]. Gerçekte ise zamanla değişen bir akımda, anahtar eğrisinin yükselen ve alçalan kısımlarında aynı debi için gözlenen seviyeler farklılık göstermektedir. Gerçek topoğrafyada taşkın dalgasının ilerlemesinin tahmini 
zemindeki kuru/sslak alan geçişleri, akımdaki süreksizlikler ve taban eğimindeki ani değişiklikler nedeniyle zorluklar taşımaktadır. Baraj yıkılması sonrası oluşan akım, modellenen alanda hidrolik sıçrama gibi süreksizlikler içerebileceği gibi, karışık (nehir-, sel-, kritik-) rejimlerde de mansapta ilerleyebilir. Taşkın dalgasının mansaptaki etkilerini incelemek için, basitleştirilmemiş haliyle dinamik denklemleri çözen iki boyutlu modeller, ya da bir boyutlu ve bu modellerin de karışık akım rejimlerine uyumlu modeller olması gereklidir.

1970'lerde kulanılmaya başlayan Coğrafi Bilgi Sistemleri (CBS) teknolojisi günümüzde sık ve yaygın olarak kullanılmaktadır. CBS verilerin düzenli bir şekilde toplanması, saklanması ve görüntülenmesinin yanısıra verilerin birbirleriyle ilişkilendirilebilmeleri açısından da analizlerde kolaylık sağlamaktadır. CBS günümüzde su kaynakları alanında da kullanılmakta, hidrolik modellerle integrasyonu sağlanarak nihai çözümler elde edilmektedir. Su kaynakları planlaması ve yönetiminde kullanım alanları arasında; toprak ve bitki örtüsü sınıflandırılması, arazi kullanımının belirlenmesi, havza sınırlarının belirlenmesi, baraj yeri seçimi ve hazne hacminin belirlenmesi, erozyon ve birikme tahminleri ve yeralt suyu modellenmesi sayılabilir.

CBS teknolojisindeki ilerlemelerin su kaynakları modellemesine en büyük katkısı; modelde kullanılan parametrelerin havza alanındaki değişimlerinin modellenebilmesine olanak sağladığı için model sonucu benzetimlerinin daha güvenli hale gelmesidir. CBS teknolojisindeki gelişmeler iki boyutlu sayısal modellerin taşkın dalgasının yayılımında sıklıkla kullanılmaya başlamasına neden olmuştur ki bu modeller arasında: Danimarka Hidrolik Enstitüsü (DHI) tarafindan geliştirilen MIKE FLOOD, Mississippi Üniversitesi Ulusal Hidrobilim ve Mühendislik Merkezi tarafindan geliştirilen CCHE2D-DAMBREAK, bir mühendislik firması tarafından geliştirilen iki boyutlu taşkın öteleme modeli olan FLO-2D ve Fransız Elektrik İdaresi (EDF) tarafindan geliştirilen TELEMAC-2D en yaygin olan modellerdir.

CCHE2D-DAMBREAK modeli, Amerika'da askeriyenin hidroloji ile alakalı çalışmalarında yaygın olarak kullanılmıştır. Model iki boyutlu sı̆̆ su denklemlerini (hidrostatik basınç kabulu ile) çözüm ağında tanımlanabilen karmaşık topoğrafya üzerinde çözmektedir. FLO-2D ise akarsu ve yerüstü akışlarının simülasyonunu gerçekleştirebilen dinamik bir taşkın öteleme modelidir. Model, tam dinamik dalga momentum (full dynamic wave) ve hacim korunum (volume conservation) denklemlerini sonlu farklar (finite difference) yöntemi kullanarak kare izgara elemanlar için çözmektedir. Böylece taşkın dalgasının hesaplama ağı sisteminde iki boyutlu yayılımını hesap etmektedir (http://www.flo-2d.com/). Standard model ücretsiz olarak dağıtıldığı gibi Amerikan Federal Acil Durum Yönetim Kurumu (FEMA) tarafından taşkın sigortalarını belirleyen çalışmalarda kullanılmaktadır.

Literatürde taşkın dalgasının ötelemesini mansap bölgesinde sayısal olarak modelleyen genelde bir boyutlu $[6,7,8,9]$ ve az da olsa iki boyutlu $[10,11,12,13]$ çalışmalar mevcuttur. Ticari yazılımların yanı sıra, araştırmacılar çalışmalarında kullanmak üzere kendi taşkın modellerini geliştirmişlerdir [14,15]. Bu modellerden LISFLOOD-FP; Bristol Üniversitesi ve $A B$ Araştırma Merkezi işbirliği ile geliştirilmiş ve karmaşık topoğrafyalarda taşkın yayılımını iki boyutlu ve raster ortamda modelleyebilmektedir [14]. Yine son zamanlarda geliştirilen bir diğer model olan FLOW-R2D ise, iki boyutlu sığ su denklemlerini kullanmakta, karmaşık topoğrafya özelliklerini CBS verisi ile modele yansıtabilmekte ve 
Baraj Ylkılması Sonrası İki Boyutlu Taşkın Yayılımının Yerleşim Bölgeleri ...

akımdaki süreksizlikleri modelde tanımlayarak taşkın dalgasının iki boyutlu yayılımını modelleyebilmektedir [15]. Türkiye'de de araştırmacılar DAMBRK ve FLDWAV modellerini Türkiye'de bulunan barajlardan bazılarına uygulamışlar ve baraj yıkılmasının etkilerini bir boyutlu modellerle incelemiş̧erdir [16,17].

İtalya'da ise araştırmacılar eskiden yıkılması gerçekleşmiş barajların yıkılma sonrası muhtemel taşkın akımlarını modelleyerek taşkının mansapta yayılımını baraj özellikleri, arazi kullanımı ve topoğrafik haritalar yardımıyla tahmin etmişler ve tarihi verilerle kıyaslamışlardır $[2,18,19]$. Bir diğer çalışmada ise, laboratuvar ortamında basitleştirilmiş baraj yıkılması sonrası kanalda oluşan akım, Navier-Stokes denklemlerini çözen FLUENT Modeli ile sayısal olarak modellenmiştir [20]. Tüm bu çalışmalarda odak noktası farklı yıkım senaryoları altında dar bir vadide taşkın dalgasının ötelenmesinin modellenmesi olmuş ve mansap topoğrafya ve arazi kullanımının entegrasyonu sınırlı kalmıştır. Bu çalışmada ise yıkılma sonrası taşkın dalgasının mansaptaki yerleşim bölgelerinde yaratacağı etki üzerinde durulmuştur. Bu amaçla, barajların yıkılması sonucu oluşan hidrograflar ve dar vadiler boyunca ötelenmeleri HEC-RAS modeli ile, taşkın dalgasının mansapta iki boyutlu olarak yayılması ve İstanbul ve Eskişehir'deki yerleşim bölgelerine etkileri FLO2D modeli uygulanarak araştırılmıştır.

\section{2. ÇALIŞMA ALANLARI}

İstanbul çok hızlı gelişmekte ve tüm hızlı gelişen şehirlerde olduğu gibi yerleşim alanlarının süratle arttığı bir şehir özelliği taşımaktadır (2014 itibarıyla nüfusu 14 milyon). Alibey Barajı 1975-1983 arası içme suyu temini amacıyla inşa edildiğinde mansap bölgeleri kırsal alan iken hali hazırda barajın tüm mansap bölgesi meskenlerle kaplı hale gelmiştir. Alibey Barajı $30 \mathrm{~m}$ yüksekliğinde, ve $2 \mathrm{hm}^{3}$ hacme sahip kaya dolgu baraj olarak yapılmış, normal su kotunda baraj haznesi $67 \mathrm{hm}^{3}$ ve göl alanı $5 \mathrm{~km}^{2}$ 'dir [21]. Barajın en kötü senaryoya göre ani yıkılma durumunda yıkıcı etkisi çok büyük olacağından ve ölümlerle sonuçlanabileceğinden bu baraj çalışma alanı olarak seçilmiştir.

Çalışma alanı olarak belirlenen diğer bir baraj ise beton ağırlık baraj olarak olarak 19661972 yılları arasında $20 \mathrm{~km}$ mansabında bulunan Eskişehir şehrine (2014 itibarıyla nüfusu 800,000) içme suyu temini, sulama ve taşkın kontrolü amaçları ile yapılan Porsuk Barajı'dır. Porsuk Baraj $150 \mathrm{~m}$ yüksekliğinde, ve $223 \mathrm{dm}^{3}$ hacme sahip, normal su kotunda baraj haznesi $525 \mathrm{hm}^{3}$ ve göl alanı $27.7 \mathrm{~km}^{2}$ dir [21]. Boyutları değerlendirildiğinde mansabında bulunan yerleşim yerlerine tehdit unsuru olarak olacağından çalışma alanı olarak seçilmiştir.

\section{YÖNTEM}

$\mathrm{Bu}$ çalışmada Alibey ve Porsuk Barajlarının yıkılması sonucu oluşacak taşkın dalgasının yayılımları sayısal model ile simüle edilmiştir. Sayısal model çalışması için; baraj göllerinin batimetri haritaları ve mansap bölgesi pürüzlülük haritası çıkartılmıştır. Batimetri haritaları sayesinde; baraj haznelerindeki su hacimleri ve dolayısı ile bir boyutlu model ile yıkılma hidrografları elde edilip, iki boyutlu sayısal modele girdi olarak vermek mümkün olmuştur. Taşkın dalgası mansap bölgesinde ilerlediği için bu bölgelerdeki pürüzlülük (evler, yollar, vs) haritaları da çıkartılmıştır. Sayısal model için girdi oluşturacak baraj gölü 
batimetri haritaları ve mansap bölgesi pürüzlülük haritaları, aşağıda özetlendiği şekilde çıkartılmışır. Barajlar ile ilgili hidrolojik raporlar ve hazne batimetrilerinin çıkartılması için gerekli haritalar DSİ Plan ve Proje Etüd Dairesi'nden, yükseklik paftaları ise Harita Genel Komutanlığı'ndan temin edilmiştir.

\subsection{Verilerin CBS ortamında olușturulması}

Günümüzde su kaynakları planlaması ve yönetiminde sıklıkla kullanılmakta olan CBS, bu çalışmada baraj haznelerinin batimetrelerinin çıkarılmasında, barajların mansap bölgelerinin sayısal yükseklik haritalarının ve arazi kullanım haritalarının oluşturulmasında kullanılmıştır.

\subsection{Baraj yıkılmasının HEC-RAS ile hidrolik modellemesi}

Baraj yıkılması HEC-RAS aracı̆̆ıılıyla üç adımda modellenmiştir: 1) Hazneye giren akımın hazne boyunca ötelenmesi, 2) baraj gediklenme özelliklerinin tahmini, 3) baraj mansabında akımın ötelenmesi. HEC-RAS modelinde taşkının haznede ötelenmesi, zamana bağlı değissen akımın kendisinin ötelenmesi ya da hazne seviyesinin ötelenmesi ile gerçekleşmektedir. Bu çalışmada sadece membadaki hazne hacmi hesaba katıldığından, hazne seviyesinin ötelenmesi yöntemi baraj yıkılması sonucu oluşan taşkın akımının modellenmesi için yeterli bulunmuştur. Bu amaçla baraj hazne içerisinde yapısal olarak tanımlanmış, biriktirme alanı belirlenmiş ve mansaptaki nehir ile ilişkilendirilmiştir. Sonrasında ise nehir hazne içerisinde de iki kesiti bulunacak şekilde tanımlanmıştır. $\mathrm{Bu}$ kesitlerden biri baraj haznesine bağlanırken diğeri baraj için sınır şartı oluşturmuştur. Böylelikle simülasyonlar esnasında baraj haznesindeki değişken su seviyesi ile mansaptaki akarsu iliş̧kilendirilmiştir. Hazne için hacim - satıh eğrisi modele girdi olarak tanımlanmış, ve akarsu üzerindeki ilk iki kesidin minumum seviyeleri, haznenin minimum seviyesine eşitlenerek modeldeki oluşabilecek muhtemel kararsızlıklar (instability) engellenmeye çalışılmıştır.

İkinci aşama gediklenme parametrelerinin tahminini içermektedir. Daha önce de belirtildiği üzere baraj yıkılması genellikle taşma ve borulanmaya bağlı olarak gerçekleşmekte ve gediklenmenin iyi tanımlanması taşkın hidrografının doğru tahmini için önem teşkil etmektedir. Ancak muhtemel bir baraj yıkılması senaryosu modellenmeye çalışıldığından gediklenmenin yeri ve şekli konusunda belirsizlikler de mevcuttur.

Üçüncü aşama ise mansapta ötelenmenin modellemesini içermektedir. HEC-RAS ile taşkın akımının mansapta akarsu boyunca ötelenmesini hassas bir şekilde modelleyebilmek için, kesit aralıklarının ve hesap zaman adımının doğru seçimi, pürüzlülüğün doğru tanımlanması ve mansap sınır şartlarının doğru belirlenmesi gerekmektedir. Daralma ve genişlemelerin, yatak eğimindeki değiş̧imlerin, pürüzlülüğün ve debinin doğru girilebilmesi için taşkının ilerlediği mansap boyunca yeterli sayıda kesit tanımlanmalıdır. Maksimum kesit aralı̆̆ için denklem (1) referans kabul edilmiş̧tir [22]:

$\Delta \mathrm{x} \leq \frac{0.15 \mathrm{D}}{\mathrm{S}}$ 
Baraj Ylkılması Sonrası İki Boyutlu Taşkın Yayılımının Yerleşim Bölgeleri ...

Denklem (1)'de $D$ ana kanalın derinliği, $S$ yatak eğimini belirtmekte ve Amerikan Ordusu Mühendisler Birliği (USACE) tarafindan baraj yıkılması taşkın akımı modelleme çalışmaları için önerilen minimum kesit aralığı 15 m olarak verilmektedir. Hesap zaman adımı, çok uzun seçildiğinde modelde kararsızlık oluşturabileceğinden ve çok kısa seçildiğinde model simülasyonu çok uzun süreceğinden Courant koşuluna göre (Denklem 2) seçilmiş̧ir.

$\Delta \mathrm{t} \leq \frac{\Delta \mathrm{x}_{\mathrm{g}}}{\mathrm{V}_{\mathrm{w}}}$

Burada $\Delta t$ zaman adımını, $\Delta x_{g}$ ızgara elemanı aralığı ve $V_{w}$ taşkın dalga hızını göstermektedir. Pratik uygulamalarda taşkın dalga hızının, modelce hesaplanan maksimum ortalama hızın 1.5 katı alınabileceği belirtilmiştir [23].

Başlangıç koşullarının simülasyon öncesi tüm kesitlerde belirli olması gerektiğinden kullanıcının başlangıç debi veya seviyeleri tüm kesitlerde girmesi gerekmektedir. Akım düşük girildiğinde, zamanla değişen akım simülasyonu başladığında program barajın altında oluşan kararsızlık nedeniyle hazneden olduğundan daha fazla akım geliyormuş gibi hesap edebilmektedir. Aynı şekilde başlangıç hazne seviyesi önemli olup, bu seviye akarsu seviyesinden çok yüksek veya çok düşük girildiğinde akarsuya debi girişi/çıkışı yüksek olacağından simülasyon başlangıcında kararsızlıklara neden olmaktadır. Modelde kararsızlığa yol açan diğer bir etken de başlangıçta bilinemeyen mansap sınır şartıdır. Mansap sınır şartı için Manning denklemi ile tanımlanan normal derinlik ya da kararlı akım simulasyonundan elde edilen debi anahtar eğrisi kullanılmaktadır.

\subsection{Taşkın dalgasının mansapta ova ve yerleşim bölgelerinde yayılmasının modellenmesi}

Dar vadi boyunca tek boyutlu ötelenen taşkın akımının ova ve yerleşim yerlerinde iki boyutlu yayılımı FLO-2D ile modellenmiştir. FLO-2D akarsu ve yerüstü akışlarının simülasyonunu gerçekleştirebilen iki boyutlu dinamik bir taşkın öteleme yazılımıdır. Model sonlu farklar yöntemi kullanarak, tam dinamik dalga momentum ve hacim korunum denklemlerini kare 1zgara elemanları için çözmektedir. Böylece iki boyutlu akım dalga yayılımı pürüzlülük özellikleri tanımlı her bir ızgara için hesaplanabilmektedir [24]. İki boyutlu modelin hesaplama sonuçlarından i) taşkının muhtemel yayılım alanı, ii) maksimum akım derinliği, iii) maksimum akım yüksekliği, iv) maksimum akım hızı ve v) maksimum akım derinliğine ulaşma zamanı her bir ızgara elemanı için hesaplama alanı dahilinde modellenmekte, elde edilen sonuçlar ArcGIS yazılımı kullanılarak haritalandırılabilmektedir.

FLO-2D modelinde iki boyutlu model sınırları taşkın dalgasının sadece tanımlı topoğrafik özelliklere bağlı olarak serbest ilerleyebileceği şekilde belirlenir. Çok büyük bir hesap alanı belirlemek çok uzun hesaplama zamanı gerektirirken, hesap alanının çok küçük seçilmesi durumunda ise mansaptaki sınır şartı membadaki taşkın akımına etki edeceğinden doğru sonuçlar vermeyecektir. $\mathrm{Bu}$ nedenle optimum bir hesap alanı seçmek gerekmekte bu da genellikle simülasyon öncesi deneme ve yanılma yöntemi ile belirlenmektedir. FLO-2D değişken zaman adımlı hesaplama yaptığından dolayı modelin kararlılığı üzerinde ızgara elemanın boyutunun herhangi bir etkisi yoktur. Ancak model simülasyon süresi izgara 
eleman boyutu küçüldükçe artar. Optimum ızgara boyutu için ise FLO-2D kullanıcı kılavuzu tarafından önerilen kriter kullanılmışır [24]:

$0.3 \mathrm{~m}^{3} / \mathrm{s} / \mathrm{m}^{2} \leq \mathrm{Q}_{\max } / \mathrm{A}_{\text {grid }} \leq 3 \mathrm{~m}^{3} / \mathrm{s} / \mathrm{m}^{2}$

burada $\mathrm{Q}_{\max }$ 1zgaradan geçen maksimum debiyi, $\mathrm{A}_{\text {grid }}$ ise ızgara alanını belirtmektedir. $\mathrm{Bu}$ çalışmada $100 \mathrm{~m} \times 100$ m'lik bir ızgara alanı seçilmiştir. Her bir ızgara elemanı için CBS tabanlı, bitki örtüsü ve arazi kullanım karakteristiklerine bağlı Manning pürüzlülük değerleri tanımlanmıştır. Bir ızgara elemanının suyu biriktirme kapasitesinin göstergesi olan alan kısıtlama katsayısı (ARF) ise alanın yüzde kaçının binalar tarafından işgal edildiğine bağlı olarak 0 ile 1 arasında değişen değerlerle tanımlanmıştır. Örneğin üzeri tamamen yapılaşmış ve suyun basamadığı bir ızgara elemanı için ARF $=1$ olmaktadır. Yerleşim alanları arka planda uydu fotoğrafları referans alınarak belirlenmiş ve ızgara elemanları için uygun ARF değerleri tanımlanmıştır. Modelin simülasyon süresi ise yapılan öncül simülasyonlar sonrası belirlenmiştir.

\section{TAŞKIN DALGASININ MODELLENMESI}

\subsection{Batimetri haritalarının oluşturulması}

Alibey ve Porsuk Baraj Göllerine ait hidrografik haritalar (4 adet Alibey için ve 9 adet Porsuk için) basılı olarak DSİ Plan ve Proje Etüd Dairesi'nden temin edilmiştir. İlk aşamada bu haritalar koordinatlandırılmış, bu işlem için evvela 'arctoolbox' arayüzündeki veri yönetim araçları sekmesi içerisindeki projeksiyon tanımlama aracı ile 'UTM-WGS 1984-Northern Hemisphere' (Kuzey Yarımküre) ve 'zone 35N.prj' seçilerek haritaların projeksiyonu seçilmiştir. Sonrasında ise 'georeferencing' aracı içindeki kontrol noktası ekleme ikonu ile haritalardan koordinatları belli olan 4 köşe için konumlar girilerek haritaların koordinatlandırılması yapılmıştır. Daha sonra ise haritaları koordinatlı olarak kaydetmek için aynı araç altındaki 'rectify' seçeneği ile gerekli düzeltmeler tamamlanmıştır [25].

Haritaları sayısallaştırma için ise depolama formatı oluşturularak eş yükselti eğrileri, derinlik ve baraj gölü katmanları yeni özellik sınıfları (featureclass) ile katmanlar oluşturularak yapılmıştır. Sayısallaştırmalar esnasında eş yükselti eğrileri için 'line', baraj gölü için 'polygon', derinlik için de 'point' seçilmiştir. Bu katmanların da koordinatlandırılmasını takiben 'editor' araç çubuğu yardımıyla eş yükselti eğrileri haritalardaki eğriler takip edilerek sayısallaştırma tamamlanmıştır.

Çizimi tamamlanan eş yükselti eğrilerinden DEM (yükseklik) haritası elde edilme işlemi yapabilmek için 'arctoolbox' arayüzündeki üç boyutlu analiz aracı olan 'TIN management' kullanılarak 'feature' özelliği taşıyan eş yükselti eğrilerini 'raster' olan DEM haritasına dönüştürmede aracılık yapan düzensiz üçgenler ağı (TIN) oluşturuldu. TINoluşumu tamamlandıktan sonra; yine aynı arayüzdeki üç boyutlu analiz aracında bulunan çevirici kullanılarak TIN olan görüntü 'raster' özelliği taşıyan görüntüye dönüştürüldü. Şekil 1 ve Şekil 2 yukarıda sırasıyla anlatılan işlemler sonucunda elde edilen Alibey Baraj Gölü ve Porsuk Baraj Gölü'ne ait batimetri haritalarını göstermektedir. Bu haritalara göre derinlik Alibey Baraj Gölü'nde 32 m'ye ve Porsuk Baraj Gölü’nde ise 54 m'ye ulaşmaktadır. 


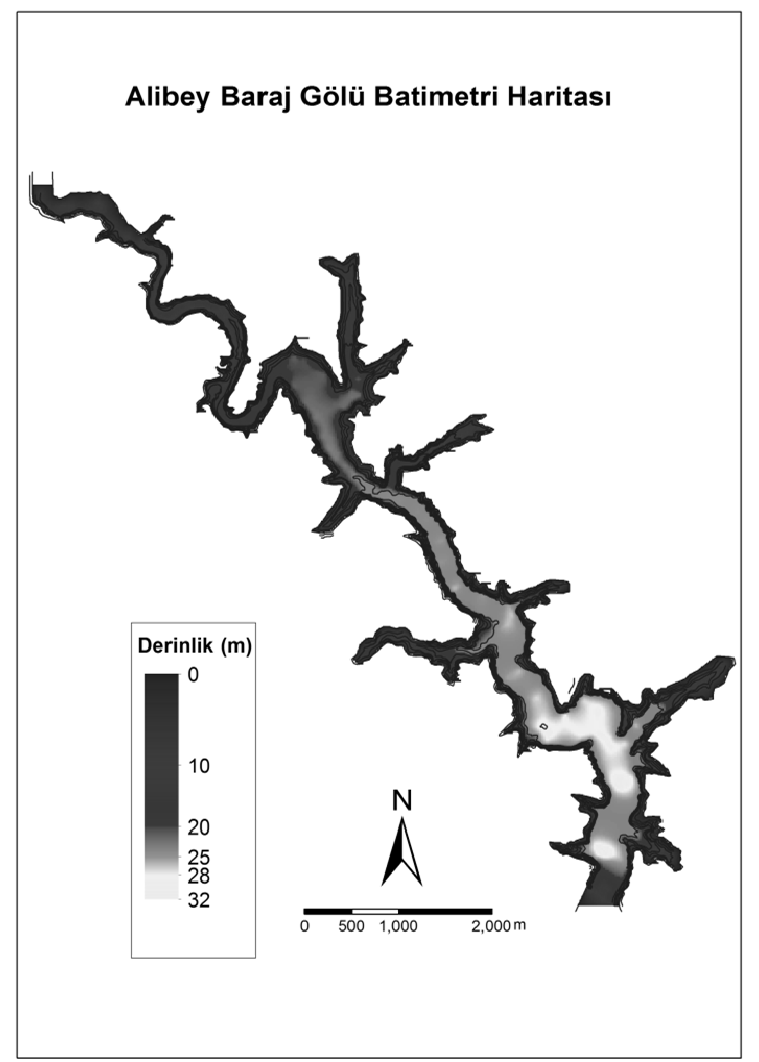

Şekil 1. Alibey Baraj Gölü’ne ait üretilmiş batimetri haritası

\subsection{Pürüzlülük haritalarının oluşturulması}

Harita Genel Komutanlığı’ndan temin edilen 1:25000 ölçekli yükseklik paftaları havza sınırının belirlenmesinde kullanıldı. Eşyükselti eğrilerinden DEM (yükseklik) haritası elde edilmesi için yine 'arctoolbox' arayüzündeki üç boyutlu analiz aracı kullanılarak düzensiz üçgenler ağı (TIN) oluşturularak çevirici yardımıyla TIN olan görüntü raster özelliği taşıyan görüntüye dönüştürüldü. Şekil 3 ve 4 Alibey ve Porsuk Barajları mansap bölgeleri için oluşturulan eş yükselti haritalarını göstermektedir [26].

Oluşturulan havza sınırı katmanının Google Earth'e aktarılabilmesi için aynı arayüzdeki çevirici kullanılarak .kmz uzantılı dosyalar elde edildi. Bu şekilde havzaya ait uydu görüntüleri resim dosyaları olarak kaydedildi. Şekil 5 Alibey barajı ve mansabını içeren uydu görüntülerinin birleştirilmesini göstermektedir. Yukarıda da anlatıldığ 1 gibi görüntülerin koordinatlanmasını takiben koordinatlı resim olarak kaydedilen uydu görüntüleri üzerinde 'arc catalog' arayüzü ile yol, bina, yeşil alan, baraj, baraj gölü ve nehir katmanları oluşturuldu ve 'editor' aracıyla sayısallaştırma işlemi yapıldı. Şekil 6 ve Şekil 7 bu aşamalar sonucu elde edilen ve iki boyutlu sayısal modele girdi teşkil eden Alibey ve Porsuk barajlarının ve mansap bölgelerinin pürüzlülük haritalarını göstermektedir [26]. 
Şebnem ELÇİ, Gökmen TAYFUR, İsmail HALTAŞ, Bülent KOCAMAN

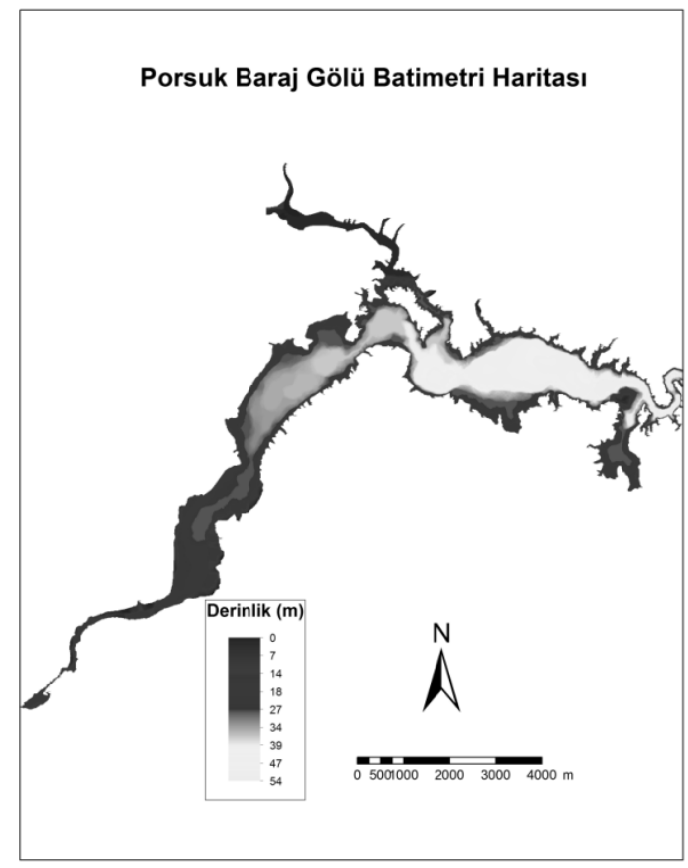

Şekil 2. Porsuk Baraj Gölü’ne ait üretilmiş batimetri haritası

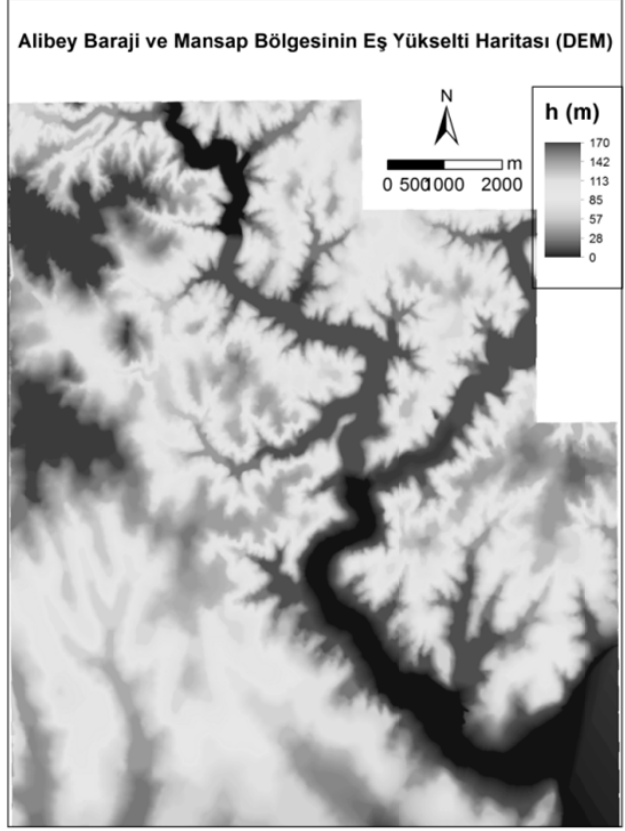

Şekil 3. Alibey Barajı ve mansap bölgesi için oluşturulan eş yükselti haritası 
Baraj Ylkılması Sonrası İki Boyutlu Taşkın Yayılımının Yerleşim Bölgeleri ...

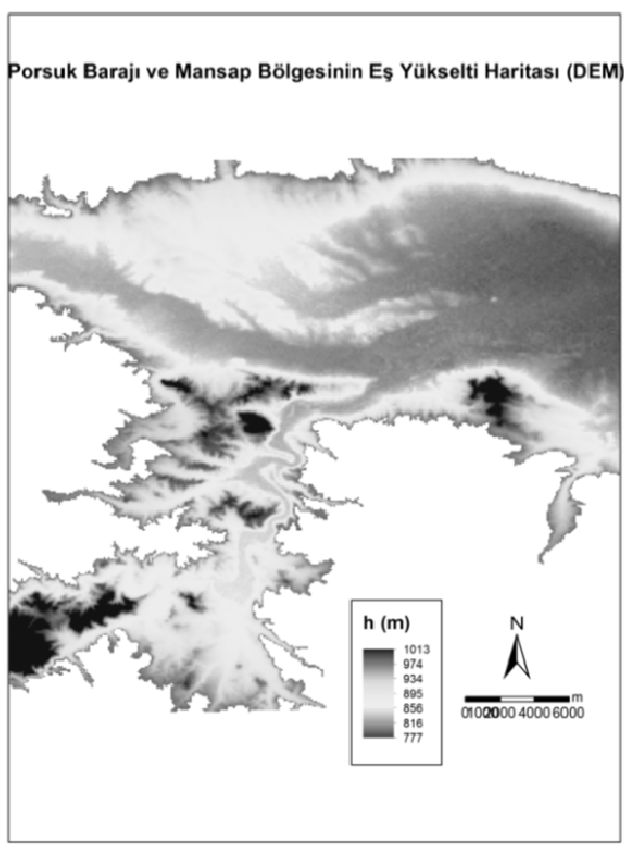

Şekil 4. Porsuk Barajı ve mansap bölgesi için oluşturulan eş yükselti haritası

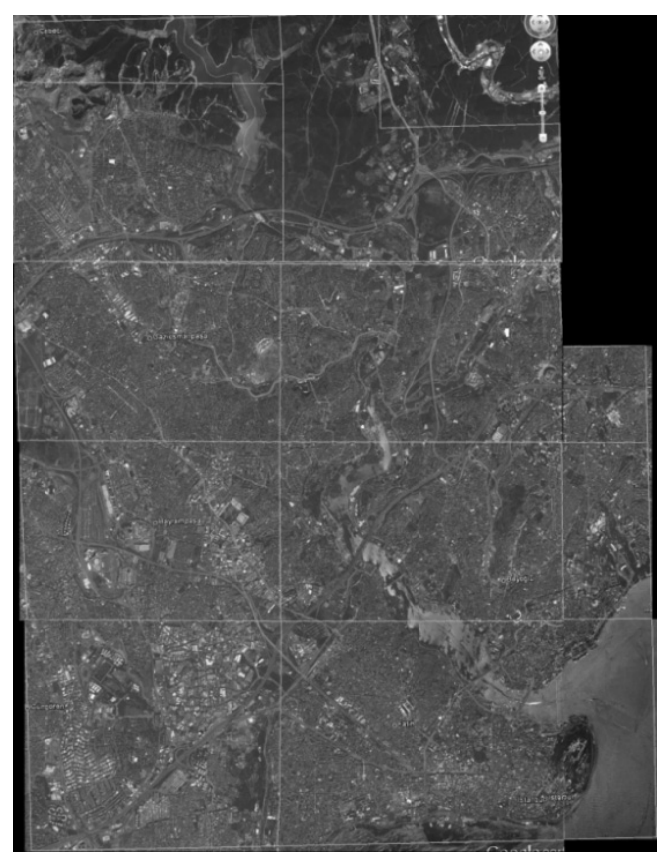

Şekil 5. Alibey Barajı ve mansap bölgesini içeren uydu görüntülerinin birleștirilmesi 
Şebnem ELÇİ, Gökmen TAYFUR, İsmail HALTAŞ, Bülent KOCAMAN

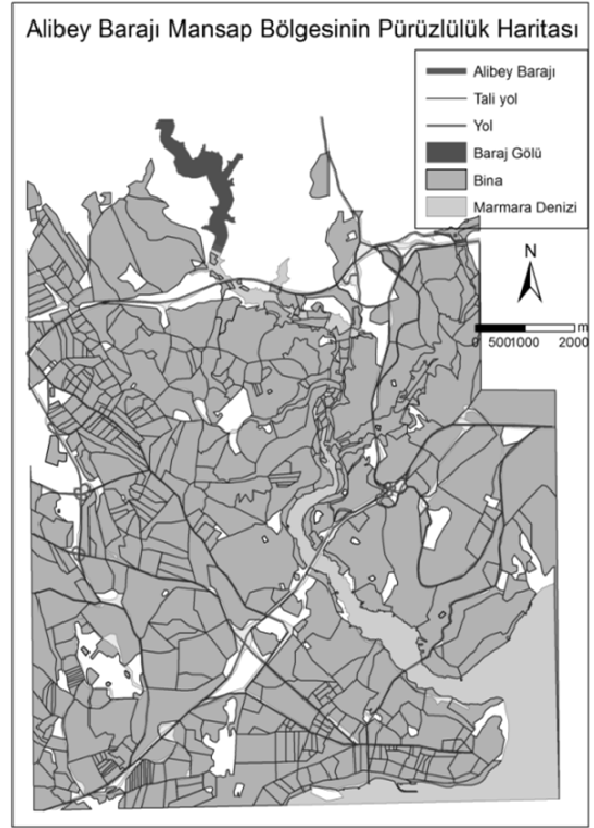

Şekil 6. Alibey Barajı ve mansap bölgesinin pürüzlülük haritası

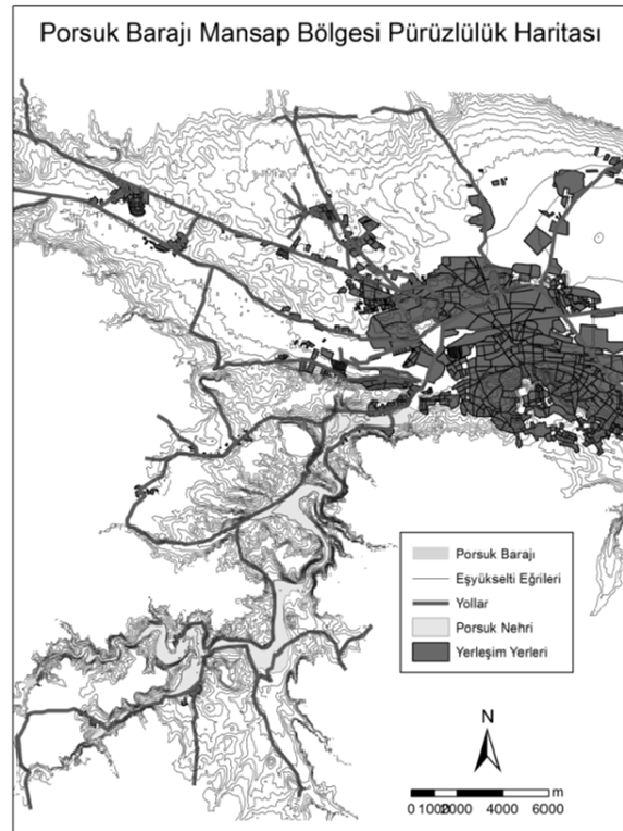

Şekil 7. Porsuk Barajı ve mansap bölgesinin pürüzlülük haritası 
Baraj Ylkılması Sonrası İki Boyutlu Taşkın Yayılımının Yerleşim Bölgeleri ...

\subsection{Baraj yıkılmasının ve oluşan taşkın hidrografının ötelenmesinin HECRAS'la modellenmesi}

Barajların olası yıkılma sonrası oluşacak taşkın hidrografları HEC-RAS 4.1.0 programı kullanılarak üç aşamada modellenmiş̧ir: i) Haznede giren akımın ötelenmesi, ii) baraj gediklenme parametrelerinin tahmini, iii) baraj mansabında taşkın akımının ötelenmesi. Sadece hazne hacmi hesaba katıldığından, hazne seviyesinin ötelenmesi yapılmıştır. $\mathrm{Bu}$ amaçla Alibey ve Porsuk baraj yıkılması simülasyonlarında kullanılan ve baraj göllerine ait batimetri haritalarından elde edilen yükselti-hacim eğrileri Şekil 8'de verilmiştir. Barajların gövdesine ait bilgiler ve baraj mansabında akarsu üzerinde alınan kesitlere ait bilgiler modele girdi verisi teşkil etmiştir. Baraj gölü su yüksekliği, hidrolik modelde memba sınır şartını oluşturmaktadır. Baraj gölünün yükselti-hacim eğrisi ise, baraj yıkılmasını modelleyen bent akış (weir flow) modülü için memba sınır şartını belirlemektedir. Borulanma türü yıkılmada orifis akım denklemi uygulanmakta ve borulanma katsayısı için de literatürde önerilen katsayı olan 0.5 [27] kullanılmıştır. Tablo 1'de seçilen barajlar için kullanılan diğer gediklenme parametreleri sunulmuştur.

Barajların mansap bölgeleri akarsular üzerinde belirli aralıklarla kesitler alınarak modellenmiştir. Bu kesitler, 'Hec-GeoRastool' arayüzündeki kesit oluşturma aracı ile oluşturulmuştur [27]. Kesitlere ait istasyon-yükselti bilgileri ise CBS ortamında eşyükselti haritalarından interpolasyonla üretilmiş 1-metre aralıklı eşyükselti eğrileri kullanılarak hesap edilmiştir. Kesitlerin yükseklik değerlerinin belirlenmesinde CBS ortamında üç boyutlu analiz aracıyla interpolasyon yaparak elde edilmiştir [27].
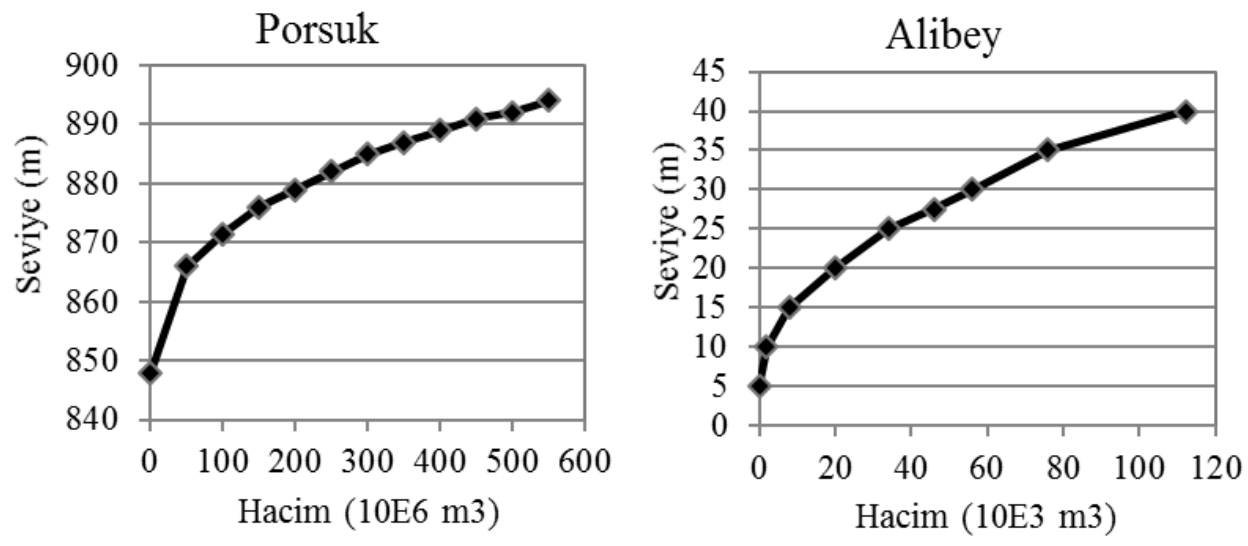

Şekil 8. Porsuk ve Alibey Baraj Gölleri için hacim- satıh eğrileri

Alibey Barajı'nın mansabındaki Alibeyköy Deresi, 50 metre aralıklarla alınmış beş adet en kesit ile modellenmiştir (Şekil 9). Porsuk akarsuyu üzerinde ise nehir genişliğinin ortalama değeri olarak 45 metre uzunluğunda ve 100'er metre aralıklarla 67 adet kesit oluşturulmuştur (Şekil 10). Tüm kesitlerin yükseklik değerleri elde edildikten sonra kesitlerin başlangıç ve bitiş noktalarının koordinatları, nehir orta çizgisinin koordinatları ve 
baraj gölü koordinatları not alınarak HEC-RAS'a girilecek veriler tamamlanmıştır. Hesaplanan taşkın hidrografları, ova ve yerleşim yerlerinde taşkın dalgasının yayılımının modellendiği iki boyutlu taşkın öteleme modelinde memba sınır şartı olarak girilmiş̧ir. Porsuk barajı için tam yıkılma sonucu oluşturulan taşkın hidrografı Şekil 11'de ve bu hidrografın $6700 \mathrm{~m}$ ötelenmiş hali Şekil 12'de gösterilmiştir.

Tablo 1. Alibey ve Porsuk Barajları için gediklenme parametreleri

\begin{tabular}{lll}
\hline Parameters & Alibey Barajı & Porsuk Barajı \\
\hline Baraj Gölü Seviyesi & $30 \mathrm{~m}$ & $870 \mathrm{~m}$ \\
Yıkılma Şekli & Borulanma & Aşarak \\
Borulanma Katsayısı & 0.5 & - \\
Baraj Tabanının Yıkılma Kotu & $10 \mathrm{~m}$ & $850 \mathrm{~m}$ \\
Baraj Tabanının Yıkılma Genişliği & $75 \mathrm{~m}$ & $60 \mathrm{~m}$ \\
Yııılma Süresi & $0.5 \mathrm{saat}$ & $0.7 \mathrm{saat}$ \\
Borulanmanın Başlama Kotu & $12 \mathrm{~m}$ & - \\
\hline
\end{tabular}

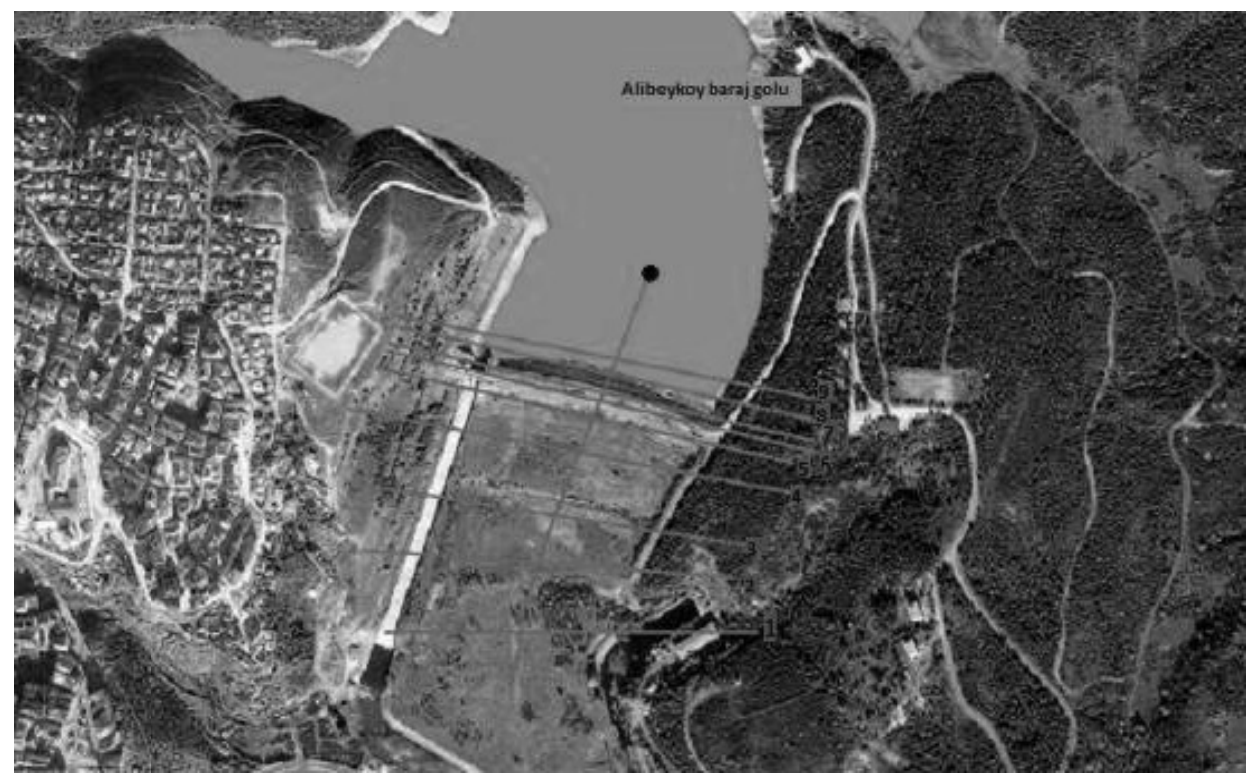

Şekil 9. Alibeyköy Deresi üzerinde oluşturulan kesitler 
Baraj Yıkılması Sonrası İki Boyutlu Taşkın Yayılımının Yerleşim Bölgeleri ...

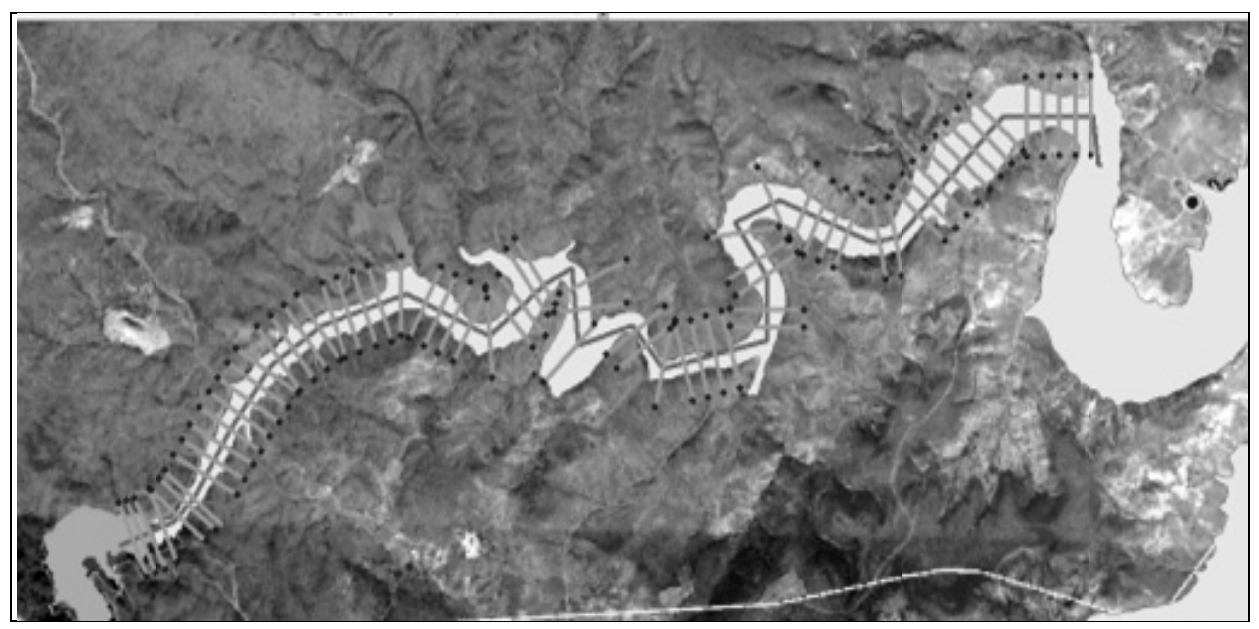

Şekil 10. Porsuk Çayı üzerinde oluşturulan kesitler

Baraj Yıkılması Sonucu Oluşan Hidrograf

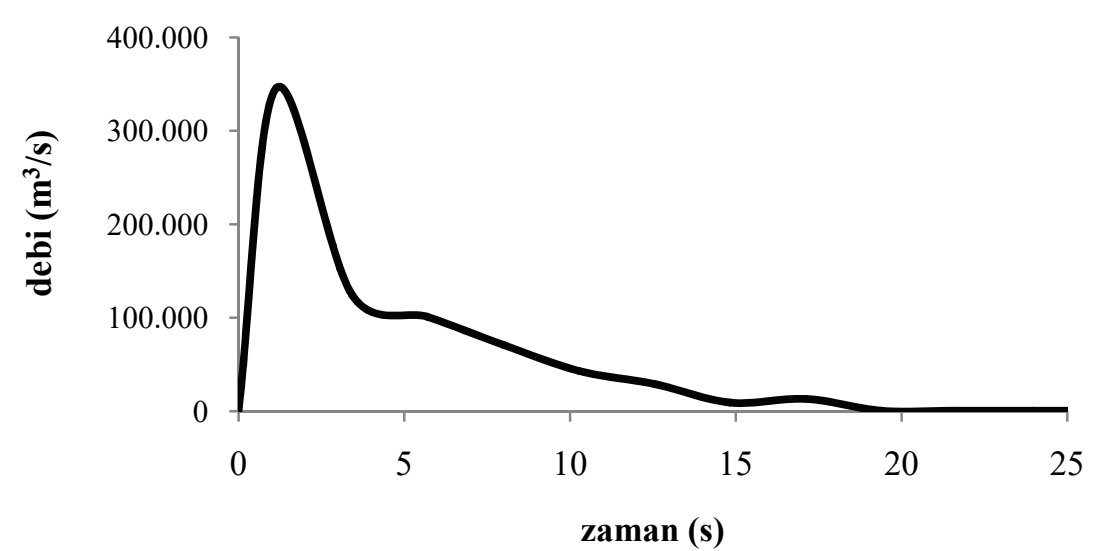

Şekil 11. Porsuk Barajı yıkılmasının ardından Porsuk Çayı üzerinde tanımlanmış ilk kesit üzerinde oluşan taşkin hidrografi 


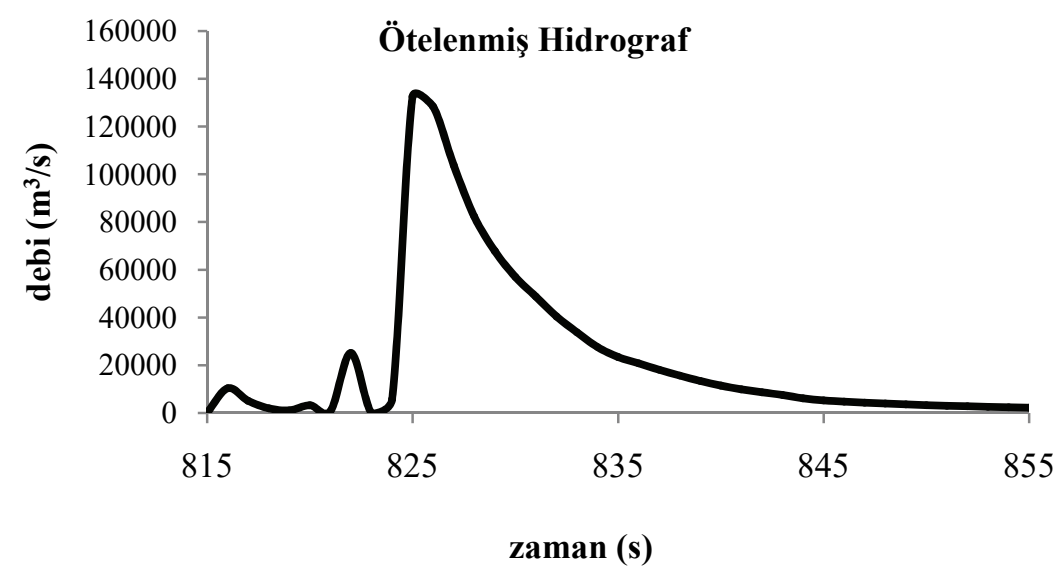

Şekil 12. Porsuk Çayı üzerinde tanımlanmış kesitler boyunca HEC-RAS ile ötelenmiş hidrograf

\subsection{Taşkın dalgasının ova ve yerleşim yerlerinde yayılımının modellenmesi}

Bir boyutlu modelden elde edilen taşkın hidrografları iki boyutlu taşkın öteleme modelinde memba sınır şartı olarak girilmiştir. Bitki örtüsü ve arazi kullanım özelliklerine bağlı olarak konumsal olarak değişken Manning pürürüzlülük katsayıları ızgara elemanları için yerleşim yerlerinde 0.02, kırsal alanlar için 0.04 olacak şekilde tanımlanmıştır. Bir ızgara elemanının yüzde kaçının binalar tarafından işgal edildiğine bağlı olarak 0 ile 1 arasında değişken değerler alan alan kısıtlama katsayısı (ARF) değerleri de arka planda uydu fotoğrafları referans alınarak belirlenmiştir. Öncül simülasyonlar sonrası taşkın dalgasının çalışma alanlarını ne kadar sürede terkettiği hesaplanmış, buna göre model Porsuk barajı için 11 saat, Alibey barajı için 3 saat için çalıştırılmıştır. Bu sürelerde pik debilerin model sınırlarına ulaştığı gözlenmiştir. Her bir ızgara elamanı için su derinliği, debi, ve akım hızı zamana bağlı olarak hesaplanmış, sonuçlar CBS shapefile formatına dönüştürülerek, FLO2D’nin sonuç sunum arayüzü Mapper yardımıyla verilmiştir.

Modelden elde edilen ani yıkılma senaryosu sonuçları maksimum akım derinlikleri için Şekil 13 ve Şekil 14'te ve maksimum akım hızları için Alibey ve Porsuk barajları için sırasıyla Şekil 15 ve Şekil 16'da verilmiştir. Alibey barajının mansabında yerleşim alanlarında taşkın dalgasının maksimum akım derinliğinin 5 m’ye ve maksimum akım hızının $5 \mathrm{~m} / \mathrm{s}^{\prime}$ ye ulaştığ yerleşim bölgesi sınırlarına ise 1 saatten daha az bir sürede ulaştı̆̆ 1 görülmektedir (Şekil 17) . Taşkın dalgasının su altında bıraktığı toplam alan yaklaşık $11.3 \mathrm{~km}^{2}$ olup bunun 9.5 $\mathrm{km}^{2}$ yerleşim alanıdır [28]. Porsuk barajının taşkın dalgası ise Eskişehir'in güneybatı sınırına (barajdan yaklaşık $20 \mathrm{~km}$ mesafede) 5.9 m maksimum akım derinliği ve $5.15 \mathrm{~m} / \mathrm{s}$ maksimum akım hızı ile ulaşmaktadır. Taşkın dalgası vadinin yerleşim alanına açıldığı bölgede 0.3 metre akım derinliğine yaklaşık 2.3 saat içerisinde ulaşmaktadır (Şekil 18), sonrasında ise yerleşim alanına doğru yayılmaya başlamıştır. Şehir merkezine bakıldığında ise model sonuçlarına göre maksimum akım derinliği 3.55 m'ye ve maksimum akım hızı $3.4 \mathrm{~m} / \mathrm{s}$ 'ye ulaşmaktadır. Taşkın dalgasının su altında bıraktığı toplam alan yaklaşık 200 $\mathrm{km}^{2}$ olup bunun $32.5 \mathrm{~km}^{2}$, si yerleşim alanıdır [29]. 
Baraj Yıkılması Sonrası İki Boyutlu Taşkın Yayılımının Yerleşim Bölgeleri ...

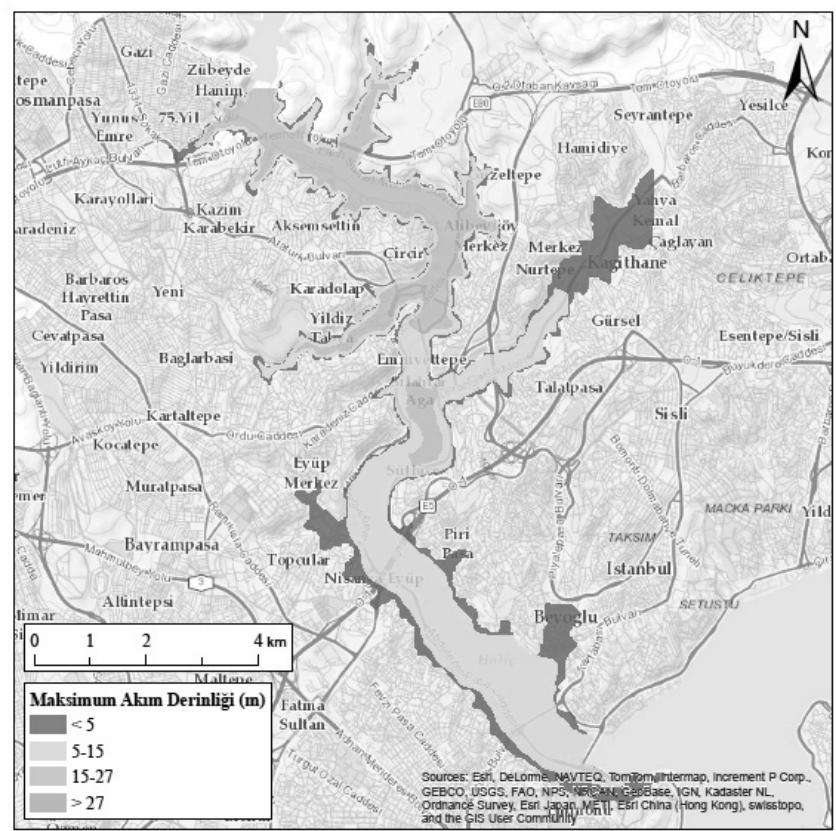

Şekil 13. Alibey Barajı yıkılması sonrası hesaplanan maksimum akım derinliği

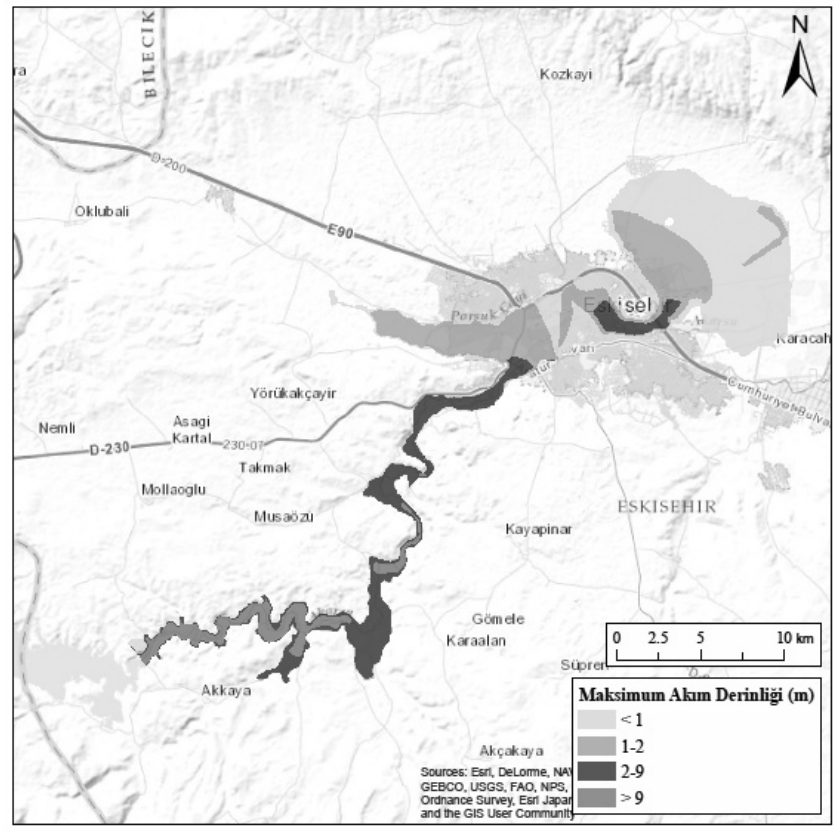

Şekil 14. Porsuk Barajı yıkılması sonrası hesaplanan maksimum akım derinliği 


\section{SONUÇLAR}

Bu çalışmada Alibey ve Porsuk barajlarının ani yıkılma senaryoları kullanılarak mansapta oluşabilecek taşkın dalgasının maksimum akım derinlikleri, akım hızları ve maksimum akım derinliğine ulaşma süreleri çok aşamalı bir modelleme yaklaşımı ile hesaplanmıştır. $\mathrm{Bu}$ aşamalar barajın ani yıkılması sonucu taşkın hidrografının elde edilmesi, HEC-RAS ile taşkın hidrografının vadi boyunca ötelenmesi ve FLO-2D ile taşkın dalgasının ova ve yerleşim yerlerinde yayılımını içermektedir. Buna ilaveten, Alibey ve Porsuk Baraj Göllerinin batimetri haritalarının çıkarılışı ve barajların mansap bölgelerinin pürüzlülük haritalarının oluşturulması ve HEC-RAS modeli için gerekli coğrafi verilerin CBS teknolojileri kullanarak hazırlanması da bu makalede sunulmuștur.

Ani yıkılma senaryosuna göre yapılan modelleme çalışması sonucu Alibey barajının mansabında yerleşim alanlarında taşkın dalgasının maksimum akım derinliğinin 5 m'ye ve maksimum akım hızının $5 \mathrm{~m} / \mathrm{s}$ 'ye ulaştığı hesaplanmıştır. $0.3 \mathrm{~m}$ akım derinliğine sahip taşkın dalgasının yerleşim bölgesi sınırlarına ise 1 saatten daha az bir sürede ulaştığı görülmüş, su altında kalan yerleşim alanı $9.5 \mathrm{~km}^{2}$ olarak hesaplanmıştır. Porsuk barajının taşkın dalgası ise Eskişehir'in güneybatı sınırına 5.9 m maksimum akım derinliği ve 5.15 $\mathrm{m} / \mathrm{s}$ maksimum akım hızı ile ulaşmaktadır. Eskişehir merkezine bakıldığında ise model sonuçlarına göre ise maksimum akım derinliği 3.55 m'ye ve maksimum akım hızı 3.4 $\mathrm{m} / \mathrm{s}$ 'ye ulaşmaktadır. Su altında kalan yerleşim alanı ise $32.5 \mathrm{~km}^{2}$ olarak hesaplanmıştır.

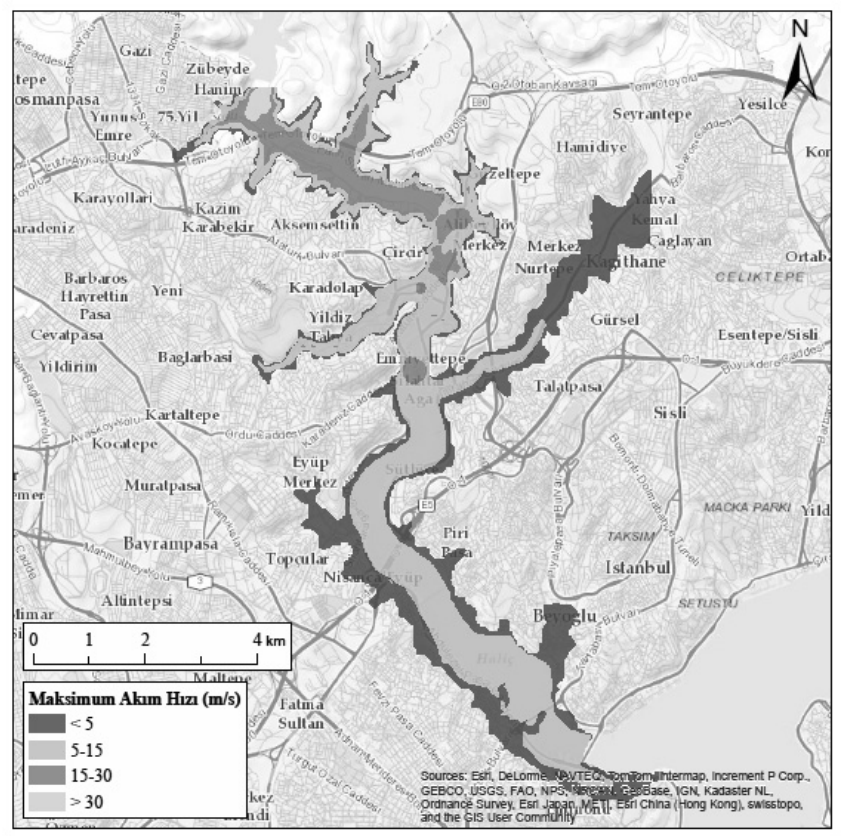

Şekil 15. Alibey Barajı yıkılması sonrası hesaplanan maksimum akım hızları 
Baraj Yıkılması Sonrası İki Boyutlu Taşkın Yayılımının Yerleşim Bölgeleri ...

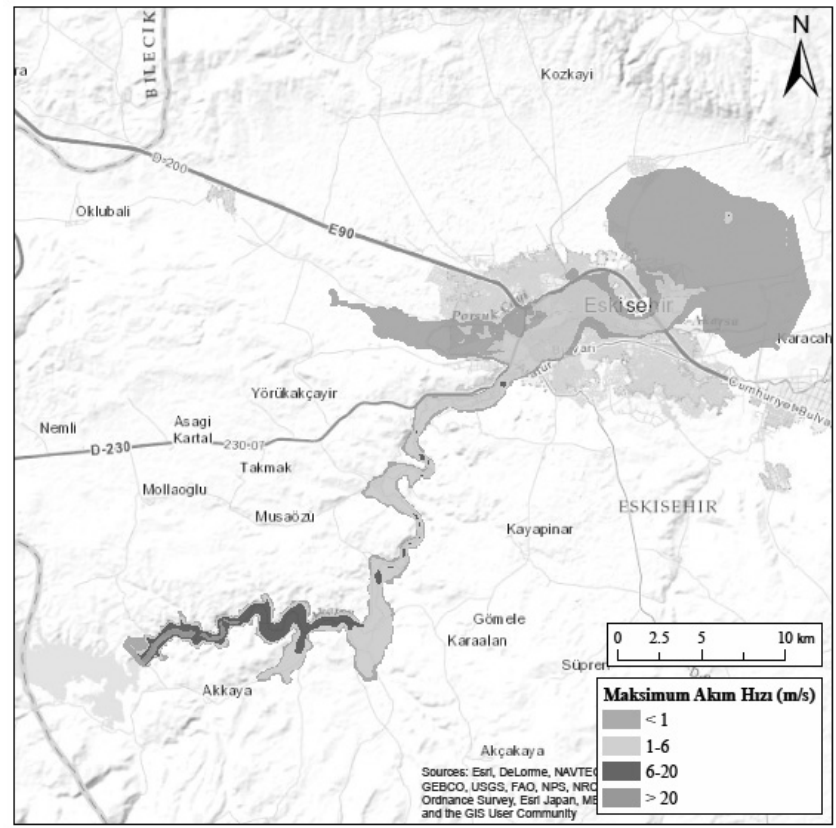

Şekil 16. Porsuk Barajı yıkılması sonrası hesaplanan maksimum akım hızları

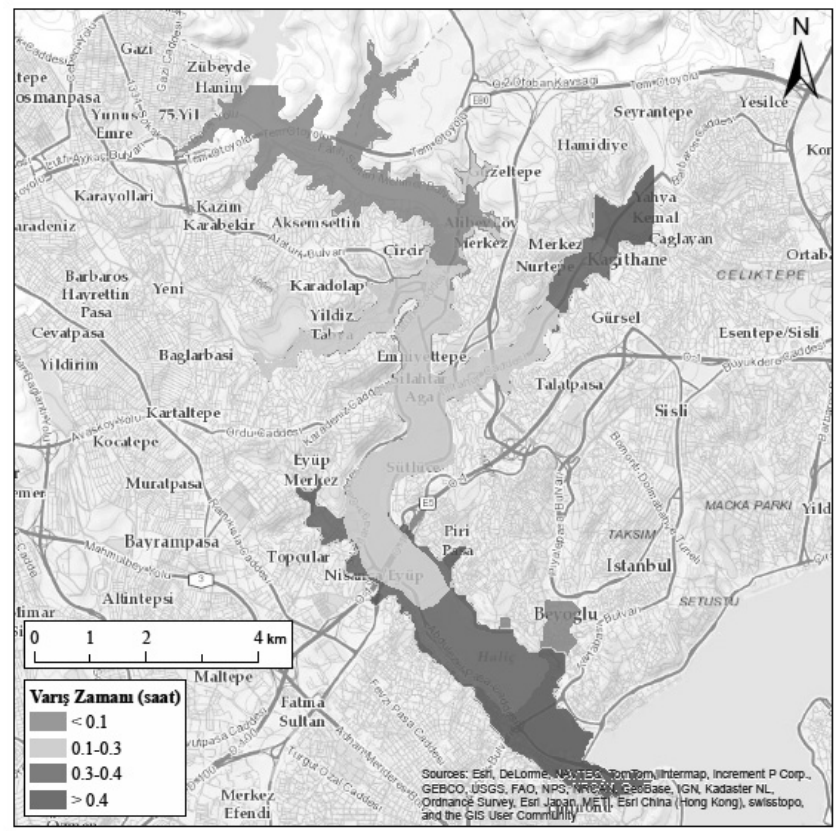

Şekil 17. Alibey Barajı yıkılması sonrası hesaplanan maksimum akım derinliğine ulaşma süreleri 
$\mathrm{Bu}$ sonuçlar ani yıkılma senaryolarına göre elde edilen öncül değerler olup, daha doğru ve hassas taşkın tehlike haritalarının oluşturulması için modeller özenli kalibrasyon işlemlerine tabi tutulmalıdır. Kalibrasyonu gerçekleştirilmiş çalışma sonuçları risk haritaları ve taşkın yönetim planlarının hazırlanmasında kullanılabileceği düşünülmektedir. $\mathrm{Bu}$ çalışmada hazne işletimi bilgisi, barajların yapısal durumu, olası gediklenme özellikleri ve muhtemel dolusavak işletim yetersizliği gibi birçok belirsizlik mevcut olduğu da ayrıca belirtilmelidir.

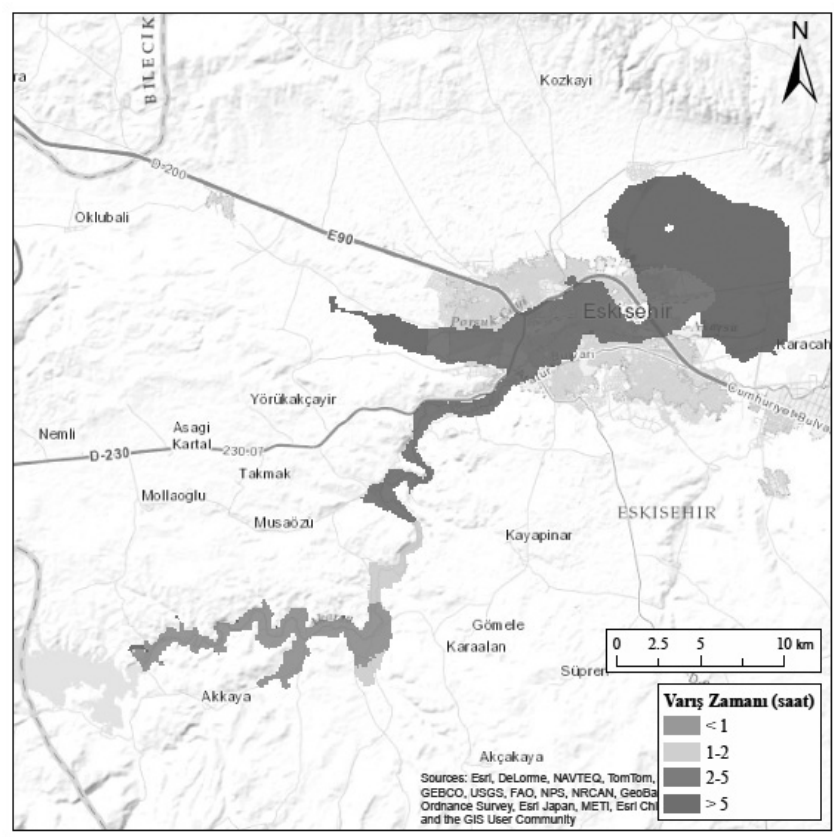

Şekil 18. Porsuk Barajı ylkılması sonrası hesaplanan maksimum akım derinliğine ulaşma süreleri

\section{Semboller}

A grid : Izgara alanı $\left(\mathrm{m}^{2}\right)$

D : Ana kanal derinliği (m)

S : Yatak eğimi

$\mathrm{Q}_{\max } \quad$ : Izgaradan geçen maksimum debiyi $\left(\mathrm{m}^{3} / \mathrm{s}\right)$

$\mathrm{V}_{\mathrm{w}} \quad$ : Taşkın dalga hızı $(\mathrm{m} / \mathrm{s})$

$\Delta \mathrm{t} \quad:$ Zaman aralığ $(\mathrm{s})$

$\Delta \mathrm{x} \quad$ : Kesit aralığ $(\mathrm{m})$

$\Delta \mathrm{x}_{\mathrm{g}} \quad$ : Izgaralar arası mesafe (m) 
Baraj Ylkılması Sonrası İki Boyutlu Taşkın Yayılımının Yerleşim Bölgeleri ...

\section{Teşekkür}

$\mathrm{Bu}$ makale 110M240 nolu TUBITAK destekli araştırma projesinden üretilmiştir. TÜBİTAK'a şükranlarımızı sunarız. Ayrıca, simülasyonun gerçekleştirilmesi için hidrolojik rapor ve batimetri bilgisini tarafımıza sağlayan DSİ Etüt ve Proje Dairesine (özellikle Dr. Bülent SELEK’e) teşekkür ederiz.

\section{Kaynaklar}

[1] Guney, M.S., Tayfur, G., Bombar, G. and Elci, S. 2014. 'Distorted Physical Model to Study Sudden Partial Dam Break Flows in an Urban Area.' J. Hydraulic Engineering, 140(11).

[2] Alcrudo, F. and Mulet, J. 2007.'Description of the Tous Dam break case study (Spain).'J. Hydraulic Research, 45, 45-58.

[3] Zhang, L. M., Xu, Y., and Jia, J. S.: Analysis of earth dam failures-A database approach, Georisk, 3, 184-189, 2009.

[4] Dinçergök, T., "The Role of Dam Safety in Dam-Break Induced Flood Management", Proceedings of International Congress on River Basin Management", pp: 682-697, March 2007, Antalya-Turkey.

[5] Altinakar 2008. Report by Working Group on Dam Issues Related to Floodplain Management submitted to Association of State Flood Plain Managers.

[6] Yanmaz, A.M., Seçkiner, G., and Özaydın, V. 2001. 'A Method for Optimum Layout Design of Concrete Gravity Dams", Water Engineering Research, International Journal of Korea Water Resources Association, Vol. 2, No:4, 199-207, October, 2001.

[7] Macchione, F. 2008. 'Model for predicting floods due to earthen dam breaching. I. Formulation and Evaluation.'J. Hydraulic Engineering, 134(12), 1688-1696.

[8] Petaccia, G. and Natale, L. 2008. 'Simulation of the SellaZerbino Catasrophic Dam Break.' In Altinakar, Kökpınar, Aydın, Çokgör and Kırkgöz (Eds) Riverflow2008, Volume 1, 601-607, Kubaba, ISBN 978-605-60136-1-4.

[9] Froehlich, D.C. 2008. Embarkment dam breach parameters and their uncertainities.J. Hydraulic Engineering, 134(12), 1708-1721.

[10] Brufau, P., Vazquez-Cendon, M.E., Garcia-Navarro P. 2002. ' A numerical model forflooding and drying of irregular domains.' Int. J. Numerical Methods Fluids, 39, 247-75.

[11] Singh, J., Altinakar, M.S. and Ding, Y. 2011 'Two-dimensional numerical modeling of dam-break flows over natural terrain using a central explicit scheme.' Advances in Water Resources, 34, 1366-1375.

[12] Qi, H. and Altinakar, M. 2012."GIS-Based Decision Support System for Dam Break Flood Management under Uncertainty with Two-Dimensional Numerical Simulations.”J. Water Resour. Plann.Manage., 138(4), 334-341.

[13] Mahdizadeh, H., Stansby, P.K. and Rogers, B.D. 2012. 'Flood Wave Modeling Based on a Two-DimensionalModified Wave Propagation Algorithm Coupled to a Full-Pipe Network Solver.' Journal of Hydraulic Engineering,138( 3), 247-259. 
[14] Bates P., Trigg, M., Neal, J. and Dabrowa, A. 2013. LISFLOOD-FP User manual, University of Bristol. Retrieved from http://www.bristol.ac.uk/medialibrary/sites/geography/migrated/documents/lisflood-manual-v5.9.6.pdf

[15] Tsakiris, G. and Bellos, V. 2014. 'A numerical model for two-dimensional flood routing in complex terrains.' Water Resources Management, 28, 1277-1291, doi:10.1007/s11269-014-0540-3.

[16] Bozkus, Z. and Guner, A.I. 2001. 'Pre-event dam failure analyses for emergency management.' Turkish J. Engineering and Environment, 25, 627-641.

[17] Bozkus, Z. and Bag, F. 2011.'Çınarcık Barajının Sanal Yıkılma Analizleri.’Teknik Dergi, (in Turkish).

[18] Pilotti, M., Maranzoni, A., Tomirotti, M., and Valerio, G. (2011). '1923 Gleno Dam break: Case study and numerical modeling.’ J. Hydraulic Engineering, 137(4), 480492.

[19] Moramarco,T., Barbetta, S., Pandolfo,C., Tarpanelli, A., Berni, N. and Morbidelli, R. 2013. 'The spillway collapse of the Montedoglio damon the Tiber River (central Italy):data collection and event analysis.' J. Hydrologic Engineering, (in press).

[20] LaRocque, L. A., Imran, J., and Chaudhry, M. H. 2013. "Experimentaland numerical investigation of two-dimensional dam-breakflows." J. Hydraul. Eng., 10.1061/(ASCE)HY.1943-7900.0000705,569-579.

[21] DSI, 2014. http://www2.dsi.gov.tr/baraj/detay.cfm?BarajID=81

[22] Samuels, P.G. 1989. "Backwater lengths in rivers", Proceedings -- Institution of Civil Engineers, Part 2, Research and Theory, 87, 571-582.

[23] USACE 2014. Using HEC-RAS for Dam-Break Studies. Report No: TD-39, USACE.

[24] FLO-2D Users Manual. Documentation. Retrieved from http://www.flo-2d.com/

[25] ESRI, 2011. ArcGIS Desktop: Release 10. Redlands, CA: Environmental Systems Research Institute.

[26] Elçi, S, Tayfur, G. Haltaş, İ. 'Baraj Yıkılması Sonrasında Taşkın Yayılımının Hesabı için Verilerin CBS Ortamında Hazırlanması: Porsuk ve Alibey Barajları Örnekleri ' Uluslararası Katılımlı IV. Ulusal Baraj Güvenliği Sempozyumu Bildiriler Kitabı, 159-170. 09-11 Ekim 2014, Elazı̆̆

[27] HEC-RAS, 2010. User's Manual. USACE Hydrologic Engineering Center, Davis, USA.

[28] Tayfur, G. , Haltaş, İ., Kocaman B., Elçi, Ș , 'Alibey Baraj Yıkılması Taşkın Dalgasının Simülasyonu' Uluslararası Katılımlı IV. Ulusal Baraj Güvenliği Sempozyumu Bildiriler Kitabı, 171-181. 09-11 Ekim 2014, Elazığ.

[29] Haltaş, İ., Kocaman B., Tayfur, G., Elçi, Ş , 'Porsuk Barajı Yıkılması Taşkın Dalgasının İki Boyutlu Modellenmesi ve Haritalandırılması' Uluslararası Katılımlı IV. Ulusal Baraj Güvenliği Sempozyumu Bildiriler Kitabı, 183-188. 09-11 Ekim 2014, Elazı ̆̆. 
